\title{
SOD1 Gene
}

National Cancer Institute

\section{Source}

National Cancer Institute. SOD1 Gene. NCI Thesaurus. Code C54578.

This gene plays a role in the detoxification of superoxide radicals in the cytosol. 